доктор педагогічних наук, професор

(Житомирський державний університет імені Івана Франка) klimov999@gmail.com

ORCID: 0000-0003-0566-4044

\title{
ІНТЕРПРЕТАЦІЯ ДРАМАТИЧНОГО ЛІТЕРАТУРНОГО ТВОРУ НА ЗАНЯТТІ ЗІ СЦЕНІЧНОӤ МОВИ У ВНЗ
}

Статтю присвячено актуальній проблемі професійного становлення мовної особистості майбутніх бакалаврів сиенічного мистецтва. Спираючись на прайі педагогів, філологів та мистецттвознавиів, автор окреслює місие інтерпретачії у роботі над драматичним твором на занятттях зі сиенічної мови.

Увага видатних акторів до мови персонажів є прикладом для наслідування студентами. Наведені фрагменти занять підтверджують думку про важливість занурення виконавия в авторський текст задля створення власного сиенічного образу.

Ключові слова: інтерпретачія, авторський задум, професійне становлення мовної особистості, драматургія, сиенічна мова, творчо-образна інтерпретачія, декодування образів художнього твору.

Постановка проблеми. "Сценічна мова" як нормативна дисципліна викладається протягом чотирьох років підготовки бакалаврів сценічного мистецтва та $є$ однією з основних у системі мистецької освіти. Ізпоміж завдань курсу визначаємо формування у студентів умінь передавати засобами сценічної мови авторський задум письменника, поєднувати його 3 власним баченням, виконувати аналіз мовних особливостей твору, вдаватися до інтерпретаиії як діяльності, пов'язаної з тлумаченням його змісту. Цілком слушною $є$ висловлювання Н. В.Грони: "Уміння інтерпретувати текст дає можливість долучитися до авторського розуміння світу, подорожувати в часі і просторі, збагачує духовно, розвиває культуру мовленнєвого спілкування" [1:28].

Актуальність дослідження. Проблема професійного становлення мовної особистості майбутніх акторів, дикторів, ведучих театралізованих заходів $є$ своєчасною, оскільки мовлення митців слугує зразком для наслідування у суспільній комунікації.

Отже, метюю статті є підкреслення ролі інтерпретації літературного тексту в професійному становленні мовної особистості майбутнього бакалавра сценічного мистецтва. Об'єктом дослідження обрано навчальне середовище ВНЗ, де здобувають освіту студенти.

Аналіз останніх досліджень. Термін "інтерпретація", відомий ще з античності, в 11-ти томному Словнику української мови визначено як "розкриття змісту чого-небудь; пояснення, витлумачення; творче розкриття образу або музичного твору виконавцем" [2: 39]. В. І. Шуляр так розуміє предмет інтерпретації: "будь-які елементи літературного твору (фрагменти, сцени, мотиви, персонажі, алегорії, символи, тропи і навіть окремі речення та слова), співвіднесені з відповідним контекстом твору або позатекстовою ситуацією" [3: 197]. Посилаючись на думку вченого, інтерпретацію драматичного твору майбутніми акторами на заняттях зі сценічної мови за типом вважатимемо творчо-образною ("перекладом" літературно-художніх творів на мову інших мистецтв"), а за рівнем - співвіднесемо 3 поняттям декодування ("розпізнаванням, дешифруванням образів та смислів художнього твору (у цьому разі приховані значення стають виявленими)") [3: 197-199]. Сутність зазначеного вище зв'язку драматургії з іншими видами мистецтва окреслює О. С. Чирков: "Драматургія - історично сформований вид мистецтва, мета і сенс якого у творенні дійства, тобто видовища, вистави, гри. Драматургія поступово поширила свою владу не лише на поезію драматичну, але й на мистецтво театральне, оперне, балетне, інструментальне, на мистецтво пантоміми, естради, цирку, кабаре і навіть банального концерту. Драматургія пройшла довгий шлях від виду драматичного мистецтва до метавиду мистецтв, видовищних за своєю сутністю" [4: 106-107].

Чому саме драматичний твір обрано об’єктом інтерпретації? Вичерпну відповідь на це запитання можна знайти в дослідженнях Н. І. Астрахан: "Драматичний твір призначається для постанови на театральній сцені. Як цілісність, він від початку був зорієнтований на матеріалізацію не художнім текстом п'єси, а виставою, театральним дійством. Вистава як творча інтерпретаційна модель драматичного літературного твору виступає як повна матеріалізація останнього. Художній текст тут отримує "звукову" матеріалізацію, він промовляється з певними інтонаціями, у певному голосовому регістрі, тобто, виступає як один $з$ можливих варіантів "конкретизації" записаного художнього тексту" [5: 139].

Виклад основного матеріалу. Формування у студентів здатності до інтерпретації літературного твору на заняттях зі сценічної мови відбувається поступово: вже на перших заняттях шляхом тестування 3'ясовуємо рівень знань першокурсників про види і жанри художньої літератури, мовні засоби художньої виразності, про історію театрального мистецтва, зокрема українського. При цьому наголошується, що 
художня література і театральне мистецтво $\epsilon$ визначальними чинниками у культурному житті суспільства. Майбутні митці досліджують творчість видатних майстрів сцени, зокрема особливості їхньої роботи над мовою персонажів.

Серед різноманітних виражальних засобів драматургії особливе місце посідає художнє слово. Світова і вітчизняна драматургія відображає красу й велич мови - майстри сцени завжди були мовленнєвими авторитетами у суспільстві, поряд з дикторами радіо і телебачення, вчителями, викладачами вищої школи, працівниками мистецьких закладів. Відомо, яку роль у формуванні культури українського мовлення в суспільстві відіграла творчість видатних акторів Марка Кропивницького, Миколи Садовського, Марії Заньковецької, Панаса Саксаганського, Гната Юри, Наталії Ужвій та ін. Зокрема, дослідники творчості Марії Костянтинівни Заньковецької зазначають, що актриса, створюючи сценічний образ, з особливою ретельністю ставилася до авторського тексту п’єси, могла навіть змінити репліки або відкинути ті рядки, які здавалися їй фальшивими. "Граючи все своє життя українських жінок-селянок, М. Заньковецька на підмостках професійної сцени возвеличувала красу українського слова" [6: 87].

Літературні драматичні твори (або уривки 3 них), призначені для інтерпретації студентами на заняттях зі сценічної мови, мають відповідати таким вимогам, як: 1) динаміка сценічної дії, гострота конфлікту, привабливість образів, цікавий сюжет; 2) високий потенціал засобів художньої виразності, індивідуалізація мови персонажів; 3) варіативність змісту реплік дійових осіб (авторського підтексту), що дає можливість студентам використовувати різні інтонації, залежно від власного бачення образів; 4) прописані у ремарках рекомендації щодо міміки й жестів персонажів, їхньої зовнішності тощо; 5) мінімум декорацій та костюмів для зручності інсценізації п’єси (уривків). Початком інтерпретації $\epsilon$ читання тексту: з'ясування змісту реплік, ремарок автора, тлумачення незнайомих слів, характеристика мови персонажів.

Як приклад, наведемо фрагмент заняття: Змістовий модуль 2. Тема: "Мова сучасних митців театру, кіно, телебачення, ведучих масових театралізованих заходів - джерело культурного збагачення українців". Тема 1. Основні тенденції вироблення норм сценічної мови. Питання 3. Мовні засоби увиразнення мови персонажів художнього твору.

\section{Завдання 1.}

1). Прочитайте уривок із драми Івана Франка "Украдене щзастя" (ява шоста). Усно перекажіть зміст уривка.

Микола, по хвилі входить Жандарм з карабіном, увесь присипаний снігом, за ним Анна.

Жандарм . Дай боже добрий вечір!

Микола. Дай боже здоровля!

Жандарм . Перепрашаю, що в таку пізню пору непрошений до вашої хати набиваюся. Але там така страшна буря, куревільниця, що не дай господи! Я з дороги збився думав уже, що або замерзну де в заметі, або вовкам на зуби попадуся.

Анна (хреститься). Господи!

Жандарм (озирається на неї, витріщуе очі, потім перемагає себе). А так! Недалеко вже було до того. Там під лісом чути, як вони виють. Кождої хвилі могли, бестії, зо мною привітатися!

Микола. Та роздягніться, пане, сідайте! Адже ж тепер, під ніч, далі не підете.

Жандарм . Та куди вже! Ніг своїх не чую, так промерз та змучився! Ой, господи тобі слава, що 3 душею 3 того снігового пекла вихопився! (Обтріпується зо снігу і починає роздягатися. Микола придивляється йому ближче.)

Микола. А ви відки, пане шандаре?

Жандарм . Та ходом з міста.

Микола. Ну, так, ходом. Але родом? Даруйте, але мені здається, що я вас десь колись бачив.

Жандарм (сміється). Ну! Чи не ще! Миколо, старий побратиме! Хіба ж ти не пізнав мене? (Клепле його по плечі.)

Микола. Михайло Гурман! Так се ти! А ми гадали... Анно, ба, а ти хіба не пізнала Михайла?

Анна (зовсім забувшися, стоїть кінець столу i, не дивлячись на них, шепче молитву). I остави, i ослаби, і відпусти, господи...

Жандарм (регочеться). Анно! Господине! Що се вам на побожність зібралося? Що ж то, не привітаєтеся зо старим знайомим?

Анна (подає йому руку). Як ся маєте, пане шандар?

Жандарм (хвилю пильно глядів на неї, потім пустив іiі руку, зціпив зуби і відвернувся, говорить далі тільки до Миколи). Ну, нинішньої ночі не забуду, доки життя мого. Знаєте, як я почув крізь вітер ті вовчі голоси, та й то так недалеко - ну, гадаю собі, вже по мені! I так мені нараз мовби хто приском поза плечима посипав. І в тій самій хвилі я побачив збоку світло. Зразу подумав, що то вовк очима блимає, але далі бачу, що стоїть на місці... I вже я нічого більше не думав, не міркував, тілько як не пущуся бігти півперек снігів, через якісь рівчаки, замети та плоти. І бог його знає, відки в мене стільки сили набралося. Гримнув чоловік собою з десять разів, то правда, але богу дякую, що хоть кості цілі! 
2) Знайдіть у словниках пояснення слів: жандарм, карабін, побратим, рівчак. Знайдіть літературні відповідники до слів: здоровля, кождий, відки, шандар, півперек, хоть. Чому автор вдається до використання їх у репліках персонажів? Знайдіть фразеологізми, поясніть значення. 3 якою метою автор застосовує їх у драмі? Охарактеризуйте мовлення кожного з персонажів.

4) Якими Ви бачите персонажів п'єси? Письмово охарактеризуйте їх.

3) Поясніть значення авторських ремарок. Прочитайте кожну репліку з ӥх урахуванням.

Зазначимо, що кожен зі студентів по-своєму "побачив" героїв твору Івана Франка. Наведемо уривки виконання письмової частини завдання (на прикладі образу Михайла Гурмана):

"Михайло Гурман глибоко страждає. Він кохає Анну, його очі сповнені сліз, оскільки жінка, яку він палко кохає, йому не належить. Голос його удавано-веселий, він намагається приховати свої почуття від Анни і Миколи, але вираз обличчя, коли він повертається спиною, відображає страждання і відчай".

"Мовлення Михайла - народно-розмовне, у ньому чимало порушень, але розповідь свідчить про його багату уяву $i$ народний гумор. Мені здається, щуо Гурман - внутрішньо сильна людина, може перебороти свої почуття. Репліки Михайло промовляє із веселою злістю, гіркою іронією. Він сердитий на Анну".

Після обговорення студенти працюють над образами в малих групах (по три чоловіки). Колективний перегляд інтерпретації твору, запропонованої кожною групою, передбачає аналіз і самоаналіз акторської гри. Цілком органічно ознайомитися зі зразками професійного виконання твору майстрами сцени (наживо або у відеозаписах).

Завдання 2.

1) Прочитайте у парах уривок із n'єси Івана Котляревського "Наталка Полтавка". Випишіть незнайомі слова, поясніть їхнє значення.

\section{Я в л е н и е 2}

\section{Іван Котляревський. "Наталка Полтавка"}

Наталка и возный.

В о 3 н ы й. Благоденственного і мирного пребиванія! (В сторону). Удобная оказія предстала зділати о собі предложеніє на самоті.

Н а т а л к а (кланяясь). Здорові були, добродію, пане возний!

В о 3 н ы й. "Добродію"! "Добродію"! Я хотів би, щоб ти звала мене - теє-то як його - не вишепом'янутим ім'ярек.

Н а т а л к а. Я вас зову так, як все село наше величає, шануючи ваше письменство і розум.

В о 3 н ы й. Не о сем, галочко, - теє-то як його - хлопочу я, но желаю із медових уст твоїх слишати умилительноє названіє, сообразноє моєму чувствію. Не в состоянії поставить на вид тобі сили любві моей. Когда би я іміл - теє-то як його - столько язиков, сколько артикулов в Статуті ілі сколько зап'ятих в Магдебурзьком праві, то і сих не довліло би навосхваленіє ліпоти твоєй! Сй-єй, люблю тебе до безконечності.

Н а т а л к а. Бог з вами, добродію! Що ви говорите! Я річі вашей в толк собі не возьму.

В о 3 н ы й. Лукавиш - теє-то як його - моя галочко! і добре все розумієш. Ну, коли так, я тобі коротенько скажу: я тебе люблю і женитись на тобі хочу.

Н а т а л к а. Гріх вам над бідною дівкою глумитися; чи я вам рівня? Ви пан, а я сирота; ви багатий, а я бідна; ви возний, а я простого роду; та й по всьому я вам не під пару.

В о 3 н ы й. Ізложенниї в отвітних річах твоїх резони суть - теє-то як його - для любові ничтожні. Уязвленное частореченною любовію серце, по всім божеським і чоловічеським законам, не взираєть ні на породу, ні на літа, ні на состояніє. Оная любов все - теє-то як його - ровняєть. Рци одно слово: "Люблю вас, пане возний!" - і аз, вишеупом'янутий, виконаю присягу о вірном і вічном союзі 3 тобою.

Н а т а л к а. У вас єсть пословиця: "Знайся кінь 3 конем, а віл з волом"; шукайте собі, добродію, в городі панночки; чи там трохи єсть суддівен, писарівен і гарних попівен? Любую вибирайте... Ось підіть лиш в неділю або в празник по Полтаві, то побачите таких гарних, що і розказати не можна.

2) Намалюйте словесний портрет пана возного. Охарактеризуйте його мовлення, опитіть, якими Ви уявляєте його зовнішність, жести, голос (висота, сила, тембр). Як Ви гадаєте, чи кохає возний Наталку?

3) Спробуйте уявити, щзо возний - негативний персонаж (недоумкуватий, нахабний, самозакоханий). Прочитайте репліки, виходячи з такого бачення образу. Потім уявіть, щяо возний позитивний герой, але трішки кумедний (кохає Наталку, поважає ї̈, намагається сподобатися, виявляє доброту).

\section{Завдання 3.}

1) Прочитайте уривок із n'єси М. Кропивницького "Дай серияю волю, заведе в неволю". Знайдіть у тексті метафори, поясніть їхнє значення для створення опису батьківщини героя. 
Ява1

М. Кропивницький " Дай серцю волю, заведе в неволю

Семен Мельниченко (йде згори шляхом, зупиняється, здійма бриля і ніби зачарований дивується). Ось і любий край, і рідне село! Давно, давно я попрощався 3 тобою, рідна батьківська оселе, дорога країно. Я покинув тебе ранньою весною; тоді ти була якась сумна, невесела, мов після пожежі, i на токах тільки де-не-де маячив невеличкий стіжечок, дерева були обголені лютою зимою... Тепер ти знов звеселіла; знов пишаєшся в скиртах та в стогах; знов хати заквітчались і потонули в зелені, і тільки де-неде біліють помеж густими садками,- то виринуть, то знову уринуть, мов лебеді на безкраїм морі. Чи знайдеться ж у світі хоч одна людина, щоб не закохалась на цей любий, тихий та веселий рай? А он далі i церковця божа, а ген ледве мріють вітряки; далі степ, степ синій, як море!... А он і хата милої - весела та світла, як погляд дівочий. Чого ж це у мене на серцеві ніби похолонуло? Руки тремтять, і голова, мов у вогні, горить... (Підходить до хати). Боже милий! Як тут гарно, скільки усякого цвіту! I свячена верба, що вдвох на вербній з завутрені принесли і посадовили, розрослась навдивовижу; мабуть, часто поливана. А он соняшник як височенно вигнався, ще й голову схилив, наче зажурився і думає тяжкі думи... Нібито він розуміє і сумує, що ось незабаром прийде зима, зв'ялить його, а буйний вітер вирве стебло з корінням і занесе його далеко...

2) Яким Ви уявлясте село? Як можна було б облаштувати сцену, щуоб відтворити красу украӥнського села?

3) Виконайте монолог Семена, використайте прийнятні, на Ваш погляд, засоби технічної виразності (голос, дихання, паузи, міміку, жести, пантоміміку).

Висновки. Зазначимо, що майбутні бакалаври сценічного мистецтва із великим задоволенням аналізують авторський текст, прагнучи осягнути авторський задум, знайти підтекст, а також розкрити власне бачення образів. Обов'язковою умовою проведення занять зі сценічної мови $\epsilon$ створення сприятливої для інтерпретації творчої атмосфери. "Лише на театральних підмостках можна осягнути сценічний твір в усій його глибині та сутності. Лише на самому спектаклі можна відчути істинну воскреслу душу п’єси в її підтексті, створеному та донесеному актором щоразу під час гри", - читаємо у книзі К.С. Станіславського "Робота актора над собою у творчому процесі втілення: Щоденник учня" [7: 87-88].

\section{СПИСОК ВИКОРИСТАНИХ ДЖЕРЕЛ ТА ЛІТЕРАТУРИ}

1. Грона Н. В. Підготовка студентів педагогічних коледжів до формування у молодших школярів текстотворчих умінь : [монографія] / Н. В. Грона. - Ніжин : ПП Лисенко М. М., 2017. - 592 с.

2. Словник української мови : в 11 т. / редкол. : І. К. Білодід (голова) та інші; Акад. наук Укр. РСР, Ін-т мовознавства ім. О. О. Потебні. - К. : Наук. думка, 1970-1980 - Т. 4, 1973. - 840 с.

3. Шуляр В. І. Стратегії літературної освіти школярів у системі профільного навчання : [монографія]/ В. І. Шуляр. - Миколаїв : Вид-во ЧДУ ім. Петра Могили, 2010. - 348 с.

4. Чирков О. С. Драматургія - мистецтво драми? // Вісник Житомирського державного університету імені Івана Франка. - Житомир : Вид-во Житомирського держ. ун-ту імені I. Франка, 2006. - № 30. - С. 104-109.

5. Астрахан Н. І. Вистава як інтерпретаційна модель драматичного твору // Вісник Житомирського державного університету імені Івана Франка. - Житомир : Вид-во Житомирського держ. ун-ту імені I. Франка, 2006. № 30. - C. 139-142.

6. Хмельницька Л. Роль та місце Марії Заньковецької у становленні та розвитку українського професійного театру // Кафедра історії та культури України. Наукові записки з української історії : [збірник наукових статей]. - Випуск 32. - Переяслав-Хмельницький, 2012.- С. 83-88.

7. Станиславский К. Работа актера над собой в творческом процессе воплощения : Дневник ученика / Константин Станиславский. - СПб. : Азбука, Азбука-Аттикус, 2017. - 416 с. - (Азбука-классика, NonFiction).

\section{REFERENCES (TRANSLATED \& TRANSLITERATED)}

1. Grona N. V. Pidgotovka studentiv pedagogichnykh koledzhiv do formuvannia $u$ molodshykh shkoliariv tekstotvorchykh umin' [Students of Pedagogical Colleges Training to Writing Skills Formation for Junior Pupils] : [monografiia] / N. V. Grona. - Nizhyn : PP Lysenko M. M., 2017. - 592 s.

2. Slovnyk ukrainskoi movy [Ukrainian Vocabulary] : v 11 t. / redkol. : I. K. Bilodid (golova) ta inshi; Akad. nauk Ukr. RSR, In-t movoznavstva im. O. O. Potebni. - K. : Nauk. dumka, 1970-1980. - T. 4, 1973. - 840 s.

3. Shuliar V. I. Strategii literaturnoi osvity shkoliariv u systemi profil'nogo navchannia [Strategies for Literary Education of Pupils in the System of Profile Education] : [monografiia]. - Mykolaiv : Vyd-vo ChDU im. Petra Mogyly, 2010. - $348 \mathrm{~s}$.

4. Chyrkov O. S. Dramaturgiia - mystetstvo dramy? [Is Drama the Art of Drama?] // Visnyk Zhytomyrskogo derzhavnogo universytetu imeni Ivana Franka [Zhytomyr Ivan Franko State University Journal]. - Zhytomyr : Vydvo Zhytomyrs'kogo derzh. un-tu imeni I. Franka, 2006. - № 30. - C. 104-109.

5. Astrakhan N. I. Vystava yak interpretatsiina model' dramatychnogo tvoru [Performance as an Interpretive Model of the Dramatic Work] / N. I. Astrakhan // Visnyk Zhytomyrskogo derzhavnogo universytetu imeni Ivana Franka 
[Zhytomyr Ivan Franko State University Journal]. - Zhytomyr : Vyd-vo Zhytomyrs'kogo derzh. un-tu imeni I. Franka, 2006. - № 30. - S. 139-142.

6. Khmelnytska L. Rol' ta mistse Marii Zankoveczkoi u stanovlenni ta rozvytku ukrainskogo profesiinogo teatru [Maria Zankovetska's Role and Place in the Development of the Ukrainian Professional Theater] // Kafedra istorii ta kul'tury Ukrainy. Naukovi zapysky z ukrainskoi istorii [Department of History and Culture of Ukraine. Scientific Notes of the Ukrainian History] : [zbirnyk naukovykh statei]. - Vypusk 32. - Pereiaslav-Khmel'nytskyi, 2012.S. 83-88.

7. Stanyslavskyi K. Rabota aktiora nad soboi v tvorcheskom protsesse voploshheniia : Dnevnyk uchenika [The Actor's Work on Himself in the Creative Process of Incarnation: Diary of a Student] / K. Stanyslavskyi. - SPb. : Azbuka, Azbuka-Attykus, 2017. - 416 s. - (Azbuka-klassyka, Non-Fiction).

\section{Климова Е. Я. Интерпретация драматического литературного произведения на занятии по сценической речи в вузе.}

Статья посвящена актуальной проблеме профессионального становления языковой личности будущих бакалавров сиенического искусства. Ссылаясь на труды педагогов, филологов, искусствоведов, автор определяет место интерпретации в работе над драматическим произведением на занятиях по сценической речи. Внимание выдающихся актеров к языку персонажей является для студентов примером для наследования. Фрагменты занятий подтверждают необходимость анализа авторского текста для создания сиенического образа.

Ключевые слова: интерпретация, авторский замысел, профессиональное становление языковой личности, драматургия, сценическая речь, творческо-образная интерпретачия, декодировка образов художественного произведения.

\section{Klymova K. Ya. Interpretation of a Dramatic Literary Work at a Lesson of the Stage Language at the University.}

The purpose of the stage language course is to form the ability to transfer the author's idea with the means of the stage language, to perform an analysis of the linguistic features of the work. The materials of the research are the dramatic works. The purpose of the article is to emphasize the role of the interpretation of the literary text in the professional development of the linguistic personality of the future bachelors. The subject of the study is the university environment. The main methods of scientific research is the process of interpreting the dramatic work, comparing the vision of the students with the author's artistic image, analyzing the content and the linguistic features of the text. Formation of students' ability to interpret a literary work is gradual: we find out the level of knowledge of the first-year students about the types and genres of fiction, language means of artistic expression, the history of the theatrical art. Future actors explore the work of outstanding actors. Researchers of the Maria Konstantinovna Zankovetskaya noted that the actress, creating a stage image, cared about the play writer's text, she could even change the replicas or reject those lines that seemed to her false. The article concludes that future bachelors analyze the author's text with great pleasure, trying to comprehend the author's idea, to find a hidden meaning, as well as to reveal their own vision of the images. The creation of a favorable atmosphere for the interpretation of the creative environment is principle.

Key words: interpretation, author's idea, professional formation of the linguistic personality, drama, stage speech, creative-figurative interpretation, decoding of images of the artistic work. 